\title{
The Effect of Ganesh Idol Immersion on the Water Quality of Gorai Jetty, Mumbai - the Environmental Health Perspective
}

\author{
Dr. Pradnya A. Lokhande \\ Assistant Professor, Bhavan's College, Andheri West, Mumbai, Maharashtra, India
}

\begin{abstract}
How to cite this paper: Dr. Pradnya A. Lokhande "The Effect of Ganesh Idol Immersion on the Water Quality of Gorai Jetty, Mumbai - the Environmental Health Perspective" Published in International Journal of Trend in Scientific Research and Development (ijtsrd), ISSN: 24566470, Volume-3 | Issue-3, April 2019, pp.398-402, URL: http://www.ijtsrd.co $\mathrm{m} /$ papers/ijtsrd228 06.pdf

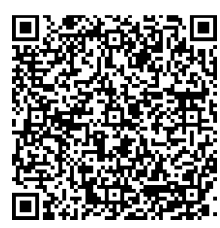
IITSRD22806
\end{abstract}

Copyright (C) 2019 by author(s) and International Journal of Trend in Scientific Research and Development Journal. This is an Open Access article distributed under the terms of the Creative Commons

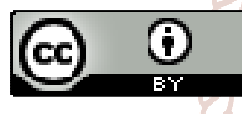
Attribution License (CC BY 4.0) (http://creativecommons.org/licenses/ by/4.0)

\section{ABSTRACT}

Water is one of the most important substances on earth. All plants and animals must have water to survive. If there was no water there would be no life on earth. Various factors play a part in this worrying state of affairs in India, such as dumped industrial and household waste and open defecation. But a surprisingly high level of pollution comes from religious ceremonies.

The Ganesh festival is one of the biggest festivals in Mumbai. These idols are made up of non-biodegradable materials like plaster of Paris (PoP) and synthetic paints used are also a major source of contamination and sedimentation. This can pose a serious threat to water quality and the flora and fauna; the festival also generates a large amount of holy waste (Nirmalya) in the form of flowers, decoration materials, oil and other religious offerings. After the festival the Ganesha idols are immersed at the various beaches and lakes and creeks across the Mumbai city.

To assess the water quality, the water samples were collected from Gorai creek before and after the Ganapati immersion and analysed for different physicochemical parameters. The parameters like pH, Temperature, DO, COD, Chloride, Sulphate, turbidity etc. were studied to find out the effect of idol immersion on quality of water. It has been observed that the values of some parameters were significantly increased during the immersion period and then declined in the post-immersion period.

Keywords: Water, Ganesh idol immersion, water pollution water quality, Physicochemical, contamination

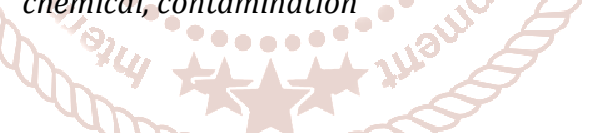

\section{INTRODUCTION}

Every year in Maharashtra, an estimated 150 million Ganesh idols are immersed in lakes, rivers and the sea during the 10day Ganesh Chaturthi festival which is celebrated traditionally in the month of August- September every year. But in Mumbai Ganpati festival is one of the public festivals celebrated by all communities with full swing. Ganesh idols are installed in colourfully decorated homes as well as at specially created structures, known as Pandals, in numerous localities.

The most serious impact of the festival on the environment is due to the immersion of idols made of Plaster of Paris into lakes, rivers and the sea. When an idol made of Plaster of Paris is immersed in the water, it changes form to gypsum, thus adding a large amount of material to the water that breaks down very slowly, while adding to the hardness of water, both of which deteriorate the life carrying capacity and quality of the water thereby causing irreversible environmental effects on the coastal ecology or the ecosystem of any water body, which in turn causes adverse environmental effects.
Plaster is a man-made material, easier to mould, lighter and less expensive than clay. However, plaster is non-

biodegradable, and insoluble in water. In terms of health impacts, paints are a greater source of hazard and most of those used for decorating idols are chemical-based. Moreover, the chemical paints used to adorn these plaster idols themselves contain heavy metals like mercury and cadmium and lead, causing water pollution.

These metals are bio-accumulative, meaning that once they enter marine life forms like fish; they pass through the food chain and end up in making the fish poisonous to the birds, animals, and people that eat them. Incidentally, the brighter the colour, the greater is its toxicity. Red, blue, orange and green colours are known to have higher content of mercury, zinc oxide, chromium and lead which seep into the water as the idol dissolves. Also, on immersion, non-biodegradable accessories that originally adorned the idol accumulate in the layers of sand on the beach.

While idols made out of naturally occurring clay (shaadu in Marathi) dissolve within hours of immersion in water, 
Plaster of Paris (PoP) idols may take anywhere between several months to years to fully dissolve. For some years now we have been observing a growing awareness about the water pollution caused by the immersion of Ganesh idols made out of Plaster of Paris, in natural water bodies such as lakes, rivers and the sea. Studies by the Central Pollution Control Board (CPCB) and scientists show a sharp rise in content of heavy metals like lead, mercury and cadmium in water bodies following idol immersions during Ganesh Chaturthi and Durga Puja festivals which endanger aquatic life.

Plaster of Paris does not dissolve easily in water and hence the idol floats on water after immersion. Ganesh Chaturthi Festival involves processions which gather large amount of crowd which is least bothered about the effects caused due to immersing these idols \& dumping garlands \& nonbiodegradable waste in \& near the various water bodies. During the immersion articles such as flowers, polythene bags, decorations, oil, plastic sheets are thrown into the water adding to the already caused damage. In present situations the materials used for making idols has led to use of non- biodegradable materials like Plaster of Paris, Plastic, thermacol, synthetic colours etc. which deteriorate the water quality.

Moreover the chemical paints used to paint these idols contain heavy metals which are potentially hazardous and bio-magnify along the food chain. Pollution due to water immersion has many social, religious, scientific and environmental dimensions. People focus on the economics of livelihoods and money- making activities to the extent that they forgot consideration of the importance of the environment and natural resources.

Environmentalists \& Scientists are concerned about the water pollution caused due to immersion of Idols during festivals like Ganesh Chaturthi or durga puja Celebrations all over India. One look to assess the harmful effects of this practice has proved to be an eye opener to many. Water is the elixir of life referred as nature, polluting it with our activities is the most devastating situation we are creating for ourselves.

Consumption of fish caught from such polluted lake over a period of time is leading to serious diseases. When organic compounds of mercury enter human body, they concentrate in the brain and destroy the cells which control the central nervous system. The toxic substances can trigger chronic ailments. Heavy metals like cadmium, lead and mercury may magnify in their concentrations and finally reach human body. Environmentalists now are worried about the water pollution and public health consequences of immersing idols in lakes and rivers.

The present investigation is focused on the water pollution of a lake caused due to immersion of Ganesha idols which is made up of plaster of Paris and chemical paints and the other religious materials (Nirmalya). The Gorai Creek is a creek off the coast of suburban Mumbai. It lies between Borivali (West) and Gorai Village. A ferry ride across the creek to Essel World, Gorai Beach and the Global Vipassana Pagoda takes around 10 to 15 minutes. The pictures below are of the geographical location of Gorai creek and the route for Ganpati visarjan at Gorai Jetty, Borivali- West respectively.
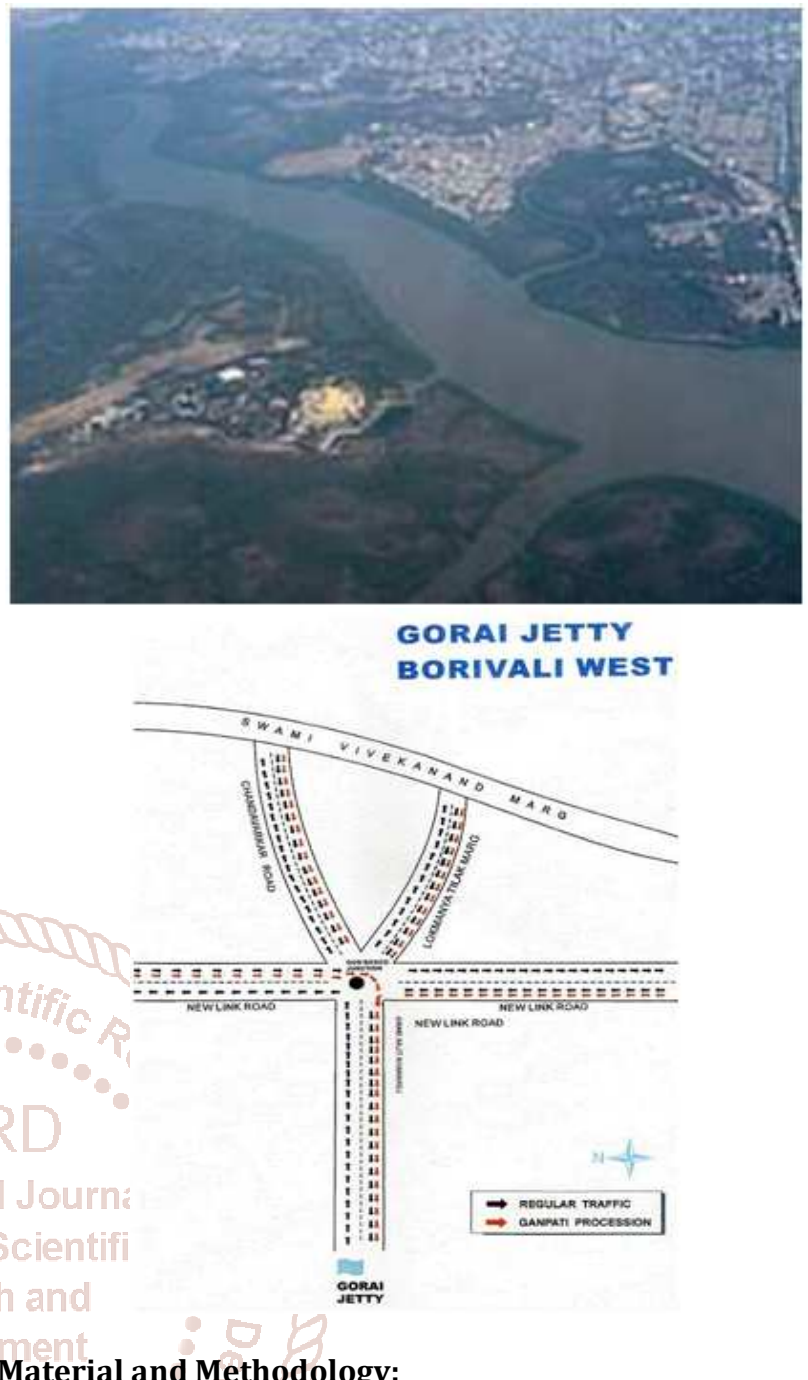

Material and Methodology:

The present investigation has been carried out The Gorai Creek, Mumbai. At Ganapati visarnjan lots of idols are immersed in the creek.

To assess the water quality the water samples was collected from surface during morning time from the place where actual immersion takes place at different time intervals i.e. before immersion and post immersion during Ganesh festival in the month of September.

$\mathrm{PoP}$ is not a naturally occurring material. Plaster of Paris is a calcium sulfate hemi-hydrate: $\left(\mathrm{CaSO}_{4}, 1 \frac{1}{2} \mathrm{H}_{2} \mathrm{O}\right)$ derived from gypsum, a calcium sulfate dihydrate $\left(\mathrm{CaSO}_{4}, 2 \mathrm{H}_{2} \mathrm{O}\right)$, by firing this mineral at relatively low temperature and then reducing it to powder. While idols made out of naturally occurring.

Before idol immersion samples were collected a week before the commencement of the immersion activities. Post idol immersion samples were collected after the completion of immersion activities. 5 litres of samples were collected in clean plastic bottles. The bottles were cleaned properly, rinsed with double distilled water before use for collection of samples.

The water analysis has been carried out as per the Bureau of Indian Standards. The water quality assessment methods include monitoring to define the condition of water, to provide the basis of detecting trends and to provide the information enabling the establishment of cause effective relationships. 
By using different physico - chemical parameters like temperature, pH, DO, BOD, COD, Chloride, Sulphate, Turbidity etc. were analysed in the laboratory and as per Standard Methods for the examination of Water and waste water.

\section{Result \& Discussion:}

There are gradual changes in all physico-chemical parameters before and after Ganapati immersion.

\section{pH:}

The $\mathrm{pH}$ of water determines the solubility (amount that can be dissolved in the water) and biological availability (amount that can be utilized by aquatic life) of chemical constituents such as nutrients (phosphorus, nitrogen, and carbon) and heavy metals (lead, copper, cadmium, etc.). For example, in addition to affecting how much and what form of phosphorus is most abundant in the water, $\mathrm{pH}$ also determines whether aquatic life can use it. In the case of heavy metals, the degree to which they are soluble determines their toxicity. Metals tend to be more toxic at lower $\mathrm{pH}$ because they are more soluble.

The average $\mathrm{pH}$ of water is 7.13 before Ganapati immersion and 7.91 after Ganapati immersion. There is change in $\mathrm{pH}$ due to the chemical or material used during the making idols. The paints and plaster of Paris contain various chemicals which effects on $\mathrm{pH}$ of water. The $\mathrm{pH}$ was determined $\mathrm{pH}$ metrically.

\section{Temperature:}

If the temperature of discharge is significantly warmer than the natural water, it can negatively affect water quality. There are several significant consequences of thermal pollution, including diminished dissolved oxygen levels, fish kills and influxes of invasive species. The temperature changes from 25.7 before immersion and 28.4 degree Celsius after immersion of idol.

\section{Do (Dissolved Oxygen):}

Dissolved oxygen refers to the level of free, non-compound oxygen present in water or other liquids. It is an important parameter in assessing water quality because of its influence on the organisms living within a body of water. In limnology (the study of lakes), dissolved oxygen is an essential factor second only to water itself. A dissolved oxygen level that is too high or too low can harm aquatic life and affect water quality. The Wrinkler's method was used to find the amount of dissolved oxygen.

Amount of DO indicates the suitability of water for flora and fauna. The DO fluctuate from $4.4 \mathrm{mg} / \mathrm{l}$ before immersion and $5.8 \mathrm{mg} / \mathrm{l}$ after immersion. This is due to increase in organic matter. Dissolved Oxygen (DO) is essential for water quality, ecological status, productivity and health of a lake. It is importance as a respiratory gas,

\section{Biochemical Oxygen Demand (BOD):}

Biochemical oxygen demand (BOD) is a measure of how much organic pollution is in water. The BOD test measures the amount of dissolved oxygen in water that is used up due to the breakdown of organic pollutants, such as sewage, in a certain number of days. BOD was determined by redox titration.
It was noticed comparatively higher post immersion period. It was found in the range of $22 \mathrm{mg} / \mathrm{L}$. in pre-immersion sample, while $56 \mathrm{mg} / \mathrm{L}$ after immersion samples respectively. The higher values of BOD means present of organic materials. The higher value of the BOD has direct correlation with the increase in nutrient level of the creek due to immersion activity.

\section{Chemical Oxygen Demand (COD):}

Biochemical oxygen demand is the amount of oxygen required for microbial metabolism of organic compounds in water. This demand occurs over some variable period of time depending on temperature, nutrient concentrations, and the enzymes available to indigenous microbial populations.

COD was determined by redox titration. It determines the amount of oxygen required for chemical oxidation of organic matter with the help of chemical oxidant, value ranges from $35.6 \mathrm{mg} / \mathrm{L}$ and $80 \mathrm{mg} / \mathrm{L}$ before and after immersion. This fluctuation shows that there is increase in chemical substances which effect on phytoplankton.

\section{Chloride:}

The ranges of chlorides changes from $5695 \mathrm{mg} / \mathrm{L}$ before and $9090 \mathrm{mg} / \mathrm{L}$ after immersion. There is increase in pollution after Ganapati visarjan showed that higher concentration of chloride is association with increased level of pollution. Chlorides were determined by Argentometric titration.

\section{Sulphate:}

The average amount of sulphate was $650 \mathrm{mg} / \mathrm{L}$ in before and after immersion $1200 \mathrm{mg} / \mathrm{L}$ this indicates that the water gets polluted due to the colours, binders etc. used for making idols activates leads to an adverse effect on the ecosystem. The amount of sulphates was determined turbidimetrically.

TSS:

Total suspended solid shows gradual changes in before and after immersion. It changes from $52 \mathrm{mg} / \mathrm{L}-131 \mathrm{mg} / \mathrm{L}$. TSS increases after immersion was more than double. Gorai creek water was comparatively clear before the immersion and after the post immersion effect of idol (Plaster of Paris and clay etc.) was seen showing comparatively high values of TSS. The method used was the filtration method to evaluate the Total suspended solids.

\section{TDS:}

The amount of Total Dissolve Solids before immersion 837 $\mathrm{mg} / \mathrm{l}$ and $18078 \mathrm{mg} / \mathrm{l}$ after immersion. Increase in values of TDS during immersion may be due to the material added while immersion of idols having solubility in water. The method used was the filtration method.

\section{Turbidity:}

It observed 34 NTU before immersion and 95 after immersion. The creek water was less turbid before immersion, high turbidity after immersion may be due to immersion of large numbers of idol which was determined nephelometrically.

\section{Oil and grease:}

It was noticed comparatively higher in during and post period. It was found nil by solvent extraction method before the immersion activity. While after activity was slightly dictated i.e. $0-0.018 \mathrm{mg} / \mathrm{L}$ respectively. The concentration of oil \& grease is quite negligible. 
All the studied parameters showed in the tabular form below in table 1.

\begin{tabular}{|c|c|c|}
\hline Parameters & Before Ganesh Immersion & After Ganesh Immersion \\
\hline pH & 7.13 & 7.91 \\
\hline Temperature $\left.{ }^{\circ} \mathrm{C}\right)$ & 25.7 & 28.4 \\
\hline DO (mg/L) & 4.4 & 5.8 \\
\hline BOD (mg/L) & 22.0 & 56.0 \\
\hline COD (mg/L) & 35.6 & 80.0 \\
\hline Chloride (mg/L) & 5695 & 9090 \\
\hline Sulphate (mg/L) & 650 & 1200 \\
\hline TSS (mg/L) & 52 & 131 \\
\hline TDS (mg/L) & 837 & 18078 \\
\hline Turbidity (NTU) & 34 & 95 \\
\hline Oil and grease (mg/L) & Nil & 0.018 \\
\hline
\end{tabular}

Table 1

As civilization progressed man invented new techniques to exploit water ecosystems. As industrialization grew, mass production was started in factories. The industrial units which came up began generating scrap and wastes. The river and ponds systems were seen as convenient and cheap way to dispose of the wastes. This had an adverse effect on human health and environment. Though not specifically intended, the process of development, urbanization, globalization and industrialization, and many anthropogenic clay (Shaadu in Marathi) dissolve within hours of immersion in water, PoP idols may take anywhere between several months to years to fully dissolve. In addition, when chemical paints are used to decorate the idols, these paints contain heavy metals such as mercury and lead, which seep into the water as the idol dissolves.

The Main Pollution is caused by the Plaster of Paris Ganesh idols and the Chemical paints used in them. Plaster of Paris is not a naturally occurring material and contains gypsum, sulphur, phosphorus and magnesium. The idols take several months to dissolve in water and in the process poison the waters of lake, ponds, rivers and seas. The Chemical Paints used to decorate the Ganesh idol contain mercury, lead, cadmium and carbon and this increases the acidity and heavy metal content water. Several accessories used during the Ganesh Puja like Thermo Cole, plastic flowers, cloth, incense, camphor and numerous other materials dumped carelessly adding more strain to the already polluted rivers and lakes. Careless immersion of Ganesh Idols in Water bodies blocks the natural flow of water. This results in stagnation and breeding of mosquitoes and other harmful pests.

\section{Conclusion:}

In the present study the immersion of Ganapati idols has negative impact on water quality. The result shows gradual changes before and after Ganapati immersion. There is increase in organic matter and chemicals which effects on flora and fauna of water.

The main reason of the deterioration of water quality is various religious activities with special blame given to the plaster of Paris, clothes, iron rods, chemical colours, varnish and paints used for making the idols and also to the Nirmalya and other things immersed with the idol.

Though a lot had been done to create awareness and implement preventive measures, the efforts have not had an impact. Year after year, the number of idols being immersed is rising significantly. To be able to choose the most appropriate eco sensitive solution it is important that we understand the environmental impacts of Ganesh Chaturthi. Since the main issue around water pollution has got to do with the idol immersion ritual, several people are now suggesting a slight variation of this ritual to avoid water pollute and solutions to avoid environmental hazards.

\section{Possible solutions:}

Several non-governmental and governmental bodies have been addressing this issue. Amongst the solutions proposed are as follows:

D Sculpture an idol only from china clay or mud

$\rightarrow$ Return to the traditional use of natural clay idols and immerse the icon in a bucket of water at home.

Use of a permanent icon made of stone and brass, used every year and a symbolic immersion only.

$>J$ Recycling of plaster idols to repaint them and use them again the following year.

$>$ Ban on the immersion of plaster idols into lakes, rivers and the sea.

$>$ Encouraging people to immerse the idols in tanks of water rather than in natural water bodies.

\section{References:}

[1] https://www.google.com/search?biw=1366\&bih=657\& tbm =isch\&sa=1\&ei=JU6TXLvqG8qSwgOI0ogBA\&q=Gora i+jetty+geographical+location\&oq=Gorai+jetty+geograp hical+location\&gs_l=img.3...32756.46644..47567 ...0.0..0. 215.2757.0j21j1..............gws-wiz-

img......0i30j0i24.VQKemghMzeo\#imgrc=h1YA3twMMRV6M:

[2] https://www.google.com/search?tbm=isch\&q=Gorai+ga npati+visarjan+site \&chips $=q$ :gorai+ganpati+visarjan + sit e,online_chips:gorai+creek\&usg=AI4_kS8qjYby_HIXr9HH93SK0-

xqdIDEA\&sa=X\&ved=0ahUKEwiBlo7o6JLhAhVFKY8KHf SGA7cQ4IYIKSgC\&biw=1366\&bih=657\&dpr=1\#imgrc $=e$ XEFK3beI44oCM:

[3] http://www.health.gov.au/internet/publications/publis hing.nsf/Content/ohp-enhealth-manual-atsi-cnt-l ohpenhealth-manual-atsi-cnt-l-ch6 ohp-enhealth-manualatsi-cnt-l-ch6.1

[4] https://www.ucanews.com/news/as-indias-rivers-turntoxic-religion-plays-a-part/70040

[5] https://www.researchgate.net/publication/298133113 _Effects_of_Ganeshidol_immersion_on_some_water_quality_parameters_of Hussainsagar_Lake 
International Journal of Trend in Scientific Research and Development (IJTSRD) @ www.ijtsrd.com eISSN: 2456-6470

[6] http://preuniversity.grkraj.org/html/4_PLANT_AND_W ATER_RELATIONSHIP.htm

[7] Shikha Saxena, Nisha Singh and Anjali Bajpai, Int. J.Chem.Sci \& Res. v6 i3, MJ 01 - 20 ISSN: 2249-0329

[8] https://water.usgs.gov/edu/ph.html

[9] https://www.fondriest.com/environmentalmeasurements/parameters/water-quality/watertemperature/
[10] https://www.fondriest.com/environmentalmeasurements/parameters/water-quality/dissolvedoxygen/)

[11] https://www.encyclopedia.com/science-andtechnology/biology-and-genetics/environmentalstudies/biological-oxygen-demand)

[12] https://en.wikipedia.org/wiki/Biochemical_oxygen_de mand

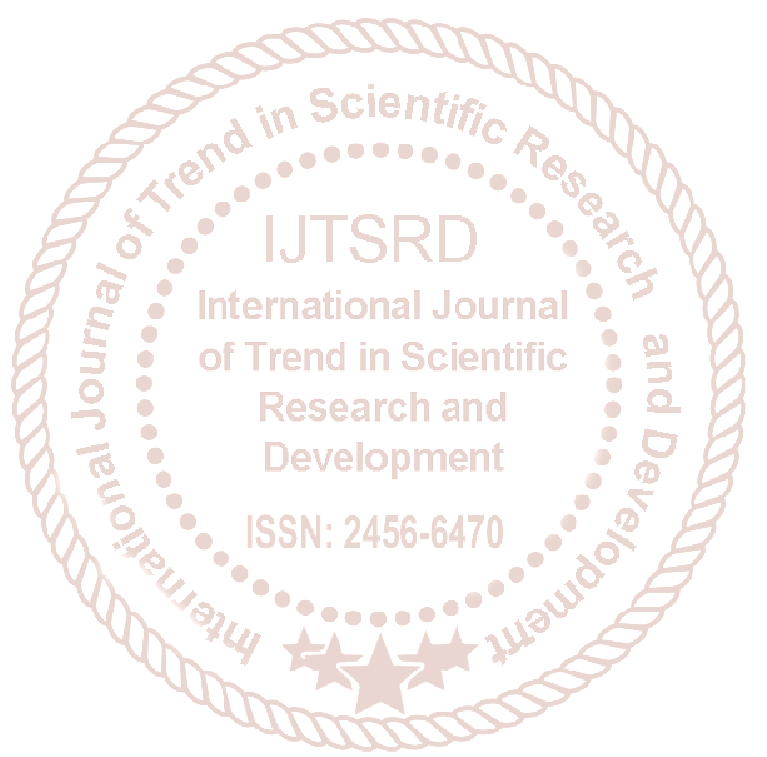

